ISSN 0258-7122 (Print), 2408-8293 (Online)

Bangladesh J. Agril. Res. 43(3): 417-430, September 2018

\title{
IMPACT OF SHARECROPPING ON RICE PRODUCTIVITY IN SOME AREAS OF KHULNA DISTRICT
}

\author{
M. F. AHMED ${ }^{1}$ AND M. M. BILLAH ${ }^{2}$
}

\begin{abstract}
The study reveals the effect of sharecropping on rice productivity in some selected areas of Khulna District in the South-West region of Bangladesh. Access to land for the landless farmer is governed by informal land tenure arrangement, which in turn affects the productivity of the rice farm. In exploring the debate on sharecropping and farm efficiency, the present study has been conducted to assess the effect of sharecropping on rice productivity. During June 2014, a field survey was conducted by using a semi-structured questionnaire in two villages of Khulna District where sharecropping is one of the dominant land tenure arrangements in rice farming. A Cobb-Douglas production function estimation showed that type of land ownership, use of fertilizers, human labor, and modern variety (MV) including hybrid seed and high yielding varieties (HYVs) of seed had the positive and significant influence on rice production. There was a significant mean difference between the sharecroppers and the owner farmers regarding their volume of rice production. The production volume of the owner farmers was significantly higher by around $781 \mathrm{~kg} \mathrm{ha}^{-1}$. The study result from the production function revealed that on an average owner farmers' output was significantly higher by $10 \%$ than that of the sharecroppers. The study also observed that higher land rent in form of a fixed amount of cash or a higher crop share demotivated the sharecroppers to supply the optimum level of input and to use the land intensively. The result implied that the sharecroppers are inefficient compared to the landowners. Therefore, it is recommended that sharing an equitable production cost and a justifiable crop sharing structure might be the better options to motivate the sharecropper to become more efficient concerning their volume of production.
\end{abstract}

Keywords: Sharecropping; Land tenancy; Rice productivity; Production function; South-West region of Bangladesh.

\section{Introduction}

Bangladesh is predominantly an agriculture based developing country and rice is the main agricultural product which is mostly contributing to the agriculture sector of Bangladesh. The area, production, and yield of rice have increased over the year (Table 1). It is seen that from 1990-1991 to 2016-2017 there is a positive growth rate (compound annual growth rate) regarding the area of overall rice cultivation, total production volume and rice yield in Bangladesh. The growth

\footnotetext{
${ }^{1}$ Assistant Professor, Economics Discipline, Khulna University, Khulna - 9208 , ${ }^{2}$ Economics Discipline, Khulna University, Khulna - 9208, Bangladesh.
} 
rate of the area, production, and yield of rice in Bangladesh were $0.2 \%, 2.39 \%$, and $2.19 \%$ respectively during the period from 1990-91 to 2016-17 (Table 1). Among the different rice production seasons, Boro is the single largest crop in Bangladesh regarding the volume of production and it is persistently contributing more compared to the Aus and Aman over the year regarding the overall rice yield. To find the study objectives, the study concentrated on the Boro rice production. In this connection, the authors reported the information on Boro rice cultivation and it is seen that the area, production, and yield of Boro rice are increasing day by day. In 2016-2017, it is estimated that Boro rice occupied nearly $41 \%$ of the 11 million hectares (ha) of rice cultivated area, and contributed more than $53 \%$ of the 33.80 million tons of rice produced. The yield (ton/ha) of Boro rice is significantly higher than Aus and Aman. The estimated yield of this rice in 2016-2017 was 4.02 ton/ha (Table 1).

The agricultural sector in Bangladesh is largely dominated by rice sub-sector and sharecropping is a widespread system in rice cultivation. Usually, the land-rich farmers cultivate a small portion of their cultivable land and rest are rented out by either sharecropping or fixed rental basis (Akanda et al., 2008). The rural marginal as well as the landless farmers largely depend on the system of share tenancy and the number of household with no won land is increasing in rural areas of Bangladesh over the time period. However, farmers having own land may also depend on others land to raise their farm size. According to a report of Bangladesh Agricultural Census, the percentages of landless households in rural areas were $12.84 \%$ in 2008 which were $10.18 \%$ in 1996, and $8.67 \%$ in 19831984 (BBS, 2008). In Bangladesh, the percentages of the owner farmers, owner cum tenant, and tenant farmers were $65.28 \%, 21.88 \%$, and $12.83 \%$, respectively, while in Khulna District, the percentages of the owner farmers, owner cum tenant, and tenant farmers were $63.44 \%, 17.16 \%$, and $19.40 \%$, respectively (BBS, 2008). This indicates that the share tenancy is a significant cultivation practice in the study area. During the shortage of off-farm employment, agricultural tenancy systems are commonly found in Bangladesh, especially at the time of cropping seasons. The system of cash tenancy and sharecropping are commonly practiced in agriculture of Bangladesh. Despite the higher prevalence of contract based cropping system in many developing countries, the yields of the sharecroppers differ than that of a fixed rent contract (Laffont and Matoussi, 1995). They found that sharecroppers exert less effort than that of a fixed rent contract, thus, production is lower for the sharecroppers.

The theoretical debate on sharecropping and agricultural productivity is observed by the model of the principal-agent relationships (Pender and Fafchamps, 2005; Laffont and Matoussi, 1995; Marshall, 1920). Marshall (1920) considers share tenancy as an inefficient practice of cultivation where resources are suboptimally utilized. The argument behind the inefficiency of sharecroppers is that the farmers are not interested in utilizing their effort optimally because a large 
portion of output goes to the landlord (Tesafa and Abera, 2014; Braido, 2008). In contrast to the Marshallian inefficiency argument, Johnson (1950) advocates that the tenant may induce to apply the efficient level of input if there is continuous monitoring of the landowners regarding the cultivation practice. If the sharecroppers are monitored then their productivity may alter. Jacoby and Mansuri (2009) found that productivity of the unmonitored sharecroppers is lower than that of the monitored sharecroppers.

Table 1. Rice Production in Bangladesh

\begin{tabular}{|c|c|c|c|c|c|c|c|c|}
\hline \multirow[b]{2}{*}{ Year } & \multicolumn{4}{|c|}{ Production Statistics of Boro Rice } & \multicolumn{4}{|c|}{ Statistics on Gross Rice Production } \\
\hline & $\begin{array}{c}\text { Area } \\
\text { ('000 } \\
\mathrm{Ha})\end{array}$ & $\begin{array}{l}\text { Prod. } \\
\text { (M. } \\
\text { Ton) }\end{array}$ & $\begin{array}{l}\text { Yield } \\
\text { (Ton/ } \\
\text { Ha) }\end{array}$ & $\begin{array}{c}\text { Annual } \\
\text { Growth } \\
\text { rate }\end{array}$ & $\begin{array}{c}\text { Area } \\
\text { ('000 } \\
\mathrm{Ha})\end{array}$ & $\begin{array}{l}\text { Prod. } \\
\text { (M. } \\
\text { Ton) }\end{array}$ & $\begin{array}{c}\text { Yield } \\
\text { (Ton/ } \\
\text { Ha) }\end{array}$ & $\begin{array}{l}\text { Annual } \\
\text { Growth } \\
\text { rate }\end{array}$ \\
\hline $1990-91$ & 2,548 & 6,357 & 2.49 & $-7.42 \%$ & 10,435 & 17,852 & 1.71 & $-2.88 \%$ \\
\hline $1991-92$ & 2,635 & 6,804 & 2.58 & $3.50 \%$ & 10,244 & 18,252 & 1.78 & $4.15 \%$ \\
\hline $1992-93$ & 2,599 & 6,586 & 2.53 & $-1.86 \%$ & 10,178 & 18,341 & 1.80 & $1.14 \%$ \\
\hline 1993-94 & 2,581 & 6,572 & 2.55 & $0.48 \%$ & 9,982 & 17,851 & 1.79 & $-0.76 \%$ \\
\hline 1994-95 & 2,664 & 6,544 & 2.46 & $-3.53 \%$ & 9,889 & 16,839 & 1.70 & $-4.78 \%$ \\
\hline $1995-96$ & 2,603 & 7,221 & 2.77 & $12.93 \%$ & 9,917 & 17,687 & 1.78 & $4.74 \%$ \\
\hline $1996-97$ & 2,783 & 7,460 & 2.68 & $-3.37 \%$ & 10,178 & 18,883 & 1.86 & $4.02 \%$ \\
\hline $1997-98$ & 2,887 & 8,145 & 2.82 & $5.25 \%$ & 9,934 & 18,291 & 1.84 & $-0.76 \%$ \\
\hline 1998-99 & 3,474 & 10,275 & 2.96 & $4.84 \%$ & 9,763 & 19,109 & 1.96 & $6.30 \%$ \\
\hline 1999-00 & 3,652 & 11,027 & 3.02 & $2.09 \%$ & 10,708 & 23,067 & 2.15 & $10.06 \%$ \\
\hline 2000-01 & 3,762 & 11,921 & 3.17 & $4.95 \%$ & 10,797 & 25,086 & 2.32 & $7.86 \%$ \\
\hline 2001-02 & 3,771 & 11,766 & 3.12 & $-1.54 \%$ & & 24,300 & 2.28 & $-1.89 \%$ \\
\hline $2002-03$ & 3,845 & 12,222 & 3.18 & $1.88 \%$ & 10,771 & 25,188 & 2.34 & $2.59 \%$ \\
\hline 2003-04 & 3,944 & 12,837 & 3.25 & $2.40 \%$ & 10,825 & 26,190 & 2.42 & $3.46 \%$ \\
\hline 2004-05 & 4,064 & 13,837 & 3.40 & $4.61 \%$ & 10,369 & 25,157 & 2.43 & $0.28 \%$ \\
\hline 2005-06 & 4,066 & 13,975 & 3.44 & $0.95 \%$ & 10,529 & 26,530 & 2.52 & $3.86 \%$ \\
\hline 2006-07 & 4,258 & 14,965 & 3.51 & $2.26 \%$ & 10,580 & 27,318 & 2.58 & $2.47 \%$ \\
\hline 2007-08 & 4,608 & 17,762 & 3.85 & $9.68 \%$ & 10,575 & 28,931 & 2.74 & $5.95 \%$ \\
\hline 2008-09 & 4,716 & 17,809 & 3.78 & $-2.03 \%$ & 11,280 & 31,317 & 2.78 & $1.48 \%$ \\
\hline $2009-10$ & 4,778 & 18,341 & 3.84 & $1.65 \%$ & 11,425 & 32,257 & 2.82 & $1.69 \%$ \\
\hline 2010-11 & 4,771 & 18,617 & 3.90 & $1.65 \%$ & 11,530 & 33,541 & 2.91 & $3.03 \%$ \\
\hline $2011-12$ & 4,810 & 18,759 & 3.90 & $-0.05 \%$ & 11,528 & 33,889 & 2.94 & $1.06 \%$ \\
\hline $2012-13$ & 4,760 & 18,778 & 3.94 & $1.15 \%$ & 11,423 & 33,833 & 2.96 & $0.75 \%$ \\
\hline 2013-14 & 4,791 & 19,007 & 3.97 & $0.56 \%$ & 11,372 & 34,356 & 3.02 & $2.00 \%$ \\
\hline
\end{tabular}


Table 1. Cont'd

\begin{tabular}{l|c|c|c|c|c|c|c|c}
\hline \multirow{2}{*}{ Year } & \multicolumn{2}{|c|}{ Production Statistics of Boro Rice } & \multicolumn{3}{|c}{ Statistics on Gross Rice Production } \\
\cline { 2 - 9 } & $\begin{array}{c}\text { Area } \\
\text { ('000 } \\
\text { Ha) }\end{array}$ & $\begin{array}{c}\text { Prod. } \\
\text { (M. } \\
\text { Ton) }\end{array}$ & $\begin{array}{c}\text { Yield } \\
\text { (Ton/ } \\
\text { Ha) }\end{array}$ & $\begin{array}{c}\text { Annual } \\
\text { Growth } \\
\text { rate }\end{array}$ & $\begin{array}{c}\text { Area } \\
\text { ('000 } \\
\text { Ha) }\end{array}$ & $\begin{array}{c}\text { Prod. } \\
\text { (M. } \\
\text { Ton) }\end{array}$ & $\begin{array}{c}\text { Yield } \\
\text { (Ton/ } \\
\text { Ha) }\end{array}$ & $\begin{array}{c}\text { Annual } \\
\text { Growth } \\
\text { rate }\end{array}$ \\
\hline $2014-15$ & 4,840 & 19,192 & 3.97 & $-0.05 \%$ & 11,415 & 34,710 & 3.04 & $0.65 \%$ \\
$2015-16$ & 4,773 & 18,938 & 3.97 & $0.07 \%$ & 11,381 & 34,710 & 3.05 & $0.30 \%$ \\
$2016-17$ & 4,476 & 18,014 & 4.02 & $1.43 \%$ & 11,001 & 33,803 & 3.07 & $0.75 \%$ \\
Mean & 3,832 & 13,101 & 3.30 & & 10,692 & 25,825 & 2.39 & \\
Std. Dev. & 871 & 4,889 & 0.58 & & 573 & 6,551 & 0.49 & \\
Growth & $2.11 \%$ & $3.93 \%$ & $1.79 \%$ & & $0.20 \%$ & $2.39 \%$ & $2.19 \%$ & \\
Rate* & & & & & & & & \\
\hline
\end{tabular}

Source: BBS (2018).

N.B.: * Growth rate $=$ Compound annual growth rate; Prod. $=$ Production; $\mathrm{Ha}=$ hectare; M. Ton $=$ Metric Ton.

The sharecroppers share their crop with the landowners on the basis of a predetermined contract. The existing sharing system is not always fairly balance the distribution of crop between tenants and landowners (Akanda et al., 2008; Zaman, 1973). Nasrin and Uddin (2011) concluded that the land tenancy structure significantly influences the use of inputs and production cost, which in turn affect the productivity. Banerjee et al. (2002) found that relatively more land rights that lead to improved crop shares and higher security of tenure for tenants may have a positive effect on productivity. Several studies (Braido, 2008; Dubois, 2002) found that the land leased out to the tenant might be of less fertile than that is cultivated by owner farmers, and thus, sharecropping is relatively inefficient. Goswami (2015) found that the sharecroppers do not consider the productivity enhancing strategy and they are reluctant to use the sufficient amount of input in agricultural production. Ray (2005) explored that the tenant farmers under-supply productivity improving investments in the land. In the context of Nepal, Acharya and Ekelund (1998) found that owner cum share tenants have more incentives to increase output by applying a significantly higher amount of family labor and other inputs in their own lands than in the shared lands they cultivate.

Several study findings revealed that there is always a debate on the performance of sharecropping in agriculture. In order to investigate the efficiency of share tenancy in agricultural productivity, an attempt has been made to highlight the tenancy structure in rice farming and its impacts on agricultural productivity in two selected rural areas of Khulna District in Bangladesh. Two categories of farmers - tenant farmers and owner farmers were considered to find the efficiency of sharecropping in rice production. In case of categorizing the type of farmers, the farmers who might have their own land, however, cultivated others 
land in a sharecropping system are considered as the sharecroppers and the farmers who cultivated rice only in their own land are considered as owner farmers. For the case of sharecroppers, the production data was collected from their land, which is in under sharecropping system and subsequently their productivity is compared with the owner farmers. The study tried to satisfy the following study objectives.

(i) To explore the existing cost and crop sharing structure under the sharecropping system in the study area;

(ii) To explore the impact of sharecropping on rice productivity in the study area.

\section{Materials and Methods}

\subsection{Description of the Study Area}

A field survey was conducted based on the multistage sampling technique in two purposively selected villages namely Raruli and Bhabanipur in Raruli Union of Paikgacha Upazila of Khulna District in Bangladesh. These two villages were known to both the authors as they were living in Khulna District at that time of the survey. For the convenience of surveying the farmers, purposively Khulna District among the Districts of the South-west region of Bangladesh then Paikgacha Upazila among the nine Upazilas was selected as the study Upazila. Then two villages namely Raruli and Bhabanipur among the two hundred and twelve villages from Paikgacha Upazila were chosen purposively. These two villages were adjacent to each other.

\subsection{Sampling Technique, Data Collection Procedure and Period of Study}

At that time of the survey, a village listing of rice cultivators (list of the farmers) was conducted in these two villages and it was found that there were about four hundred rice farmers in these two villages who were the concerned population of this study. As the objectives of this study were to find the role of sharecropping on rice productivity, two categories of farmers - sharecropper and owner farmer in rice cultivation were taken for this study to find out their production difference. To make a balance between these two groups, the primary data were collected from a total of 80 respondents randomly taking 40 from the owner farmers and 40 from the sharecroppers which were a mixture of pure sharecroppers and fixed rental based tenants. The pure sharecroppers share the output (crop amount) with the landowners in a pre-determined proportion, some cases 50:50 share and in other cases 65:35, whereas in a fixed rental system of cultivation, a fixed amount of money paid annually to the landowners by the cultivators ranged from BDT 4,000 to BDT 6,000 [1 US $\$=78.00$ Bangladeshi Taka at the time of survey] per hectare of land depend ing on the land fertility 
and accessibility of land. The sharecroppers might have some amount of their own land. However, this study only considered the information on their cultivated land, which is in under sharecropping system. In order to find the role of sharecropping on rice productivity, the study collected the data on rice production and input use from the rice production plots of landowners and the production plots of sharecroppers.

A semi-structured questionnaire was used to collect the data from 80 samples of these two villages. A draft questionnaire was prepared and it was pre-tested through a pilot survey. The pilot survey was conducted during the middle of May 2014. After a careful scrutiny based on the observations from pilot survey and field visits, the final version of the questionnaire was prepared for the household survey, which was conducted in June 2014. The questionnaire covered - the socio-economic condition of the farmer, land holding, tenancy structure, farming type, use of inputs, output, existing crop sharing practice, etc. The information on rice cultivation covered the Boro rice which is usually cultivated during January to May in each year.

\subsection{Analytical Technique}

To determine the output differentials between the sharecropper and owner farmer, the hypotheses were tested by using the t-test. The study also used a kernel distribution curve to find the production structure between the sharecroppers and owner farmers. This curve showed the production distribution of both the group of farmers and the enveloped area represented the density of each group.

In order to assess the effect of sharecropping on rice productivity, a CobbDouglas form of production function was estimated (Equation 1). In the production function, land ownership pattern of the farm was used as a dummy (1 for owner farmer and 0 for sharecropper) along with several other explanatory variables such as land size, number of labor, use of seed, use of fertilizers, use of pesticides, cost of irrigation, cost of ploughing, nature of farming, farming experience, cropping pattern and crop rotation are used as the explanatory variables.

$$
\operatorname{Ln} \mathrm{Q}=\beta_{\mathrm{n}}+\beta_{i} \operatorname{Ln} X_{i}+\beta_{i} D_{i}+u_{i} \ldots \ldots \ldots \ldots \ldots \ldots \ldots \ldots \text { (1) }
$$

In equation $1, \mathrm{Q}$ is yield of rice ( $\mathrm{kg} \mathrm{ha}^{-1}$; 'ha' is refers to 'hectare'), $\mathrm{X}_{1}$ is land size (ha), $X_{2}$ is use of seed $\left(\mathrm{kg} \mathrm{ha}^{-1}\right), X_{3}$ is use of fertilizers (kg ha-1), $X_{4}$ is use of labor (man days ha-1), $\mathrm{X}_{5}$ is use of pesticides $\left(\mathrm{kg} \mathrm{ha}^{-1}\right), \mathrm{X}_{6}$ is cost of ploughing $\left(\mathrm{BDT} \mathrm{ha}^{-1}\right), \mathrm{X}_{7}$ is cost of irrigation (BDT ha-1), $\mathrm{X}_{8}$ is farming experience (years), $\mathrm{X}_{9}$ is household size, $\mathrm{D}_{1}$ is a dummy for type of seed (1 for modern variety and 0 for others), $\mathrm{D}_{2}$ is a dummy for ownership pattern of the farm (1 for owner farm 
and 0 for sharecropper), $\mathrm{D}_{3}$ is a dummy for training in farming (1 for having training in rice cultivation and 0 for having no training), $\mathrm{D}_{4}$ is a dummy for nature of farming ( 1 for full-time farming and 0 for not doing rice cultivation as full time), $\mathrm{D}_{5}$ is a dummy for crop rotation ( 1 for the same crop in each season and 0 for different crops in each alternate seasons), and $\mathrm{D}_{6}$ is a dummy for cropping pattern ( 1 for single crop and 0 for more than single crop). The dummy for ownership pattern of the farm is used to find the production difference between the sharecroppers and owner farmers.

\section{Results and Discussion}

\subsection{Patterns of Crop Sharing Under the Tenancy Contracts}

There are three types of farming practice prevailed in rice cultivation in the study areas such as owner farming, owner cum tenant farming and tenant farming based on the crop sharing and rental system. The pattern of crop sharing depends on the cost sharing of inputs and other assistance. Traditionally, there was a proportion of crop sharing of 50 percent for the owner and the rest 50 percent for the cultivator. At present, the scenario of crop sharing has been changed because of increasing cost of production. The sharecroppers in the study area were unable to invest in crop production and seek financial assistance from the landowners.

In many cases, the landowners did not share the cost of production, thus, received less than 50 percent of output. In contrast, when a landowner shares the cost of production then he or she receives more than half or sometimes exactly half of the output. When a sharecropper bears all the cost of production then he or she gets 65 percent of output (Fig. 1). Nasrin and Uddin (2011) observed that a large number of sharing agreements under the pure share tenancy in Bangladesh mostly dependent on the proportion of cost sharing. Islam and Maharjan (2015) observed that in most of the cases the landowner takes 50 percent of the produced crops without sharing any portion of production costs and in less than 5 percent of the cases the sharing pattern was more than $50 \%$.

The study result indicated that out of 20 pure sharecroppers, 60 percent (12 out of 20 pure sharecroppers) of them reported 50:50 share (Fig. 1) where both the farmers (landowner and tenant) got equal portion of output and the rest 40 percent of the sharecroppers (eight out of 20 pure sharecroppers) reported 65:35 share where the sharecroppers got 65 percent and the owner farmers got 35 percent of the output (Fig. 1). For the case of 50:50 share of output, the landowners shared half of the cost of irrigation and fertilizers, and for the case of 65:35 ratio of output, the sharecroppers bore all the cost of production. In this case, the landowners got the crop as the rent of land without sharing any cost of 
production. This finding revealed that there was a significant association between the crop share and the rate of production cost-sharing by the landowners. In a study on a North Indian village, Sharma and Drèze (1996) claimed that the relationship between landlord and tenant was often assumed to be inherently unequal and exploitative.

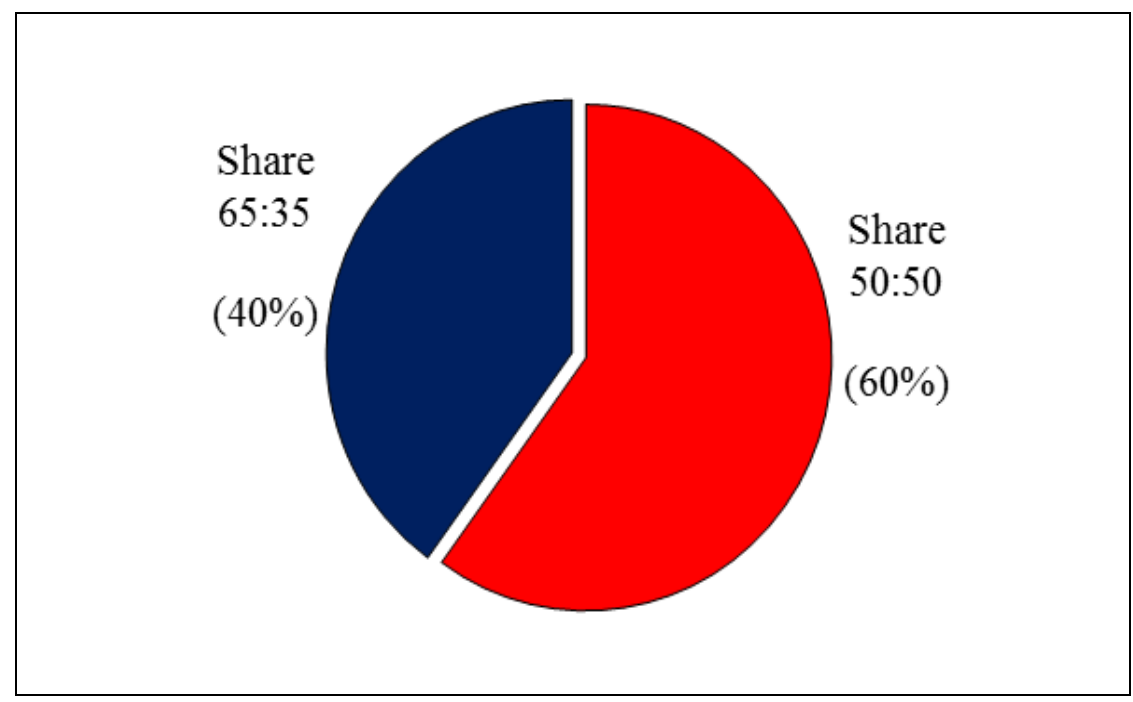

Fig. 1. Sharing Pattern of Output in the Study Area (Percent).

Source: Authors compilation based on field survey (2014)

\subsection{Impact of Sharecropping on Rice Productivity}

From the study findings, it was observed that there was a significant mean production difference between the owner farmers and sharecroppers (Table 2). During the Boro rice cultivation [January to May], the mean output of an owner farmer was $\sim 6114 \mathrm{~kg} \mathrm{ha}^{-1}$, while the mean output of a sharecropper was $\sim 5332 \mathrm{~kg}$ $\mathrm{ha}^{-1}$ which revealed a significant production difference between these two categories of farmer. The findings illustrated the farm's efficiency level under different tenancy structure by comparing their mean output per hectare of land. In addition, the study also observed that the owner farmers were more productive than their counterparts (sharecroppers). The kernel distribution curve showed that the distribution of the owner farmers enveloped a higher density in the range of the higher value of $\log$ of rice production $\left(\mathrm{kg} \mathrm{ha}^{-1}\right)$ (Fig. 2). On the contrary, for the sharecroppers, a higher density was observed in the range of the lower value of $\log$ of rice production as compared to the owner farmers. The findings indicated that the sharecroppers suffered from the productive inefficiency, the while the landowners were mostly better off in terms of productive efficiency. 


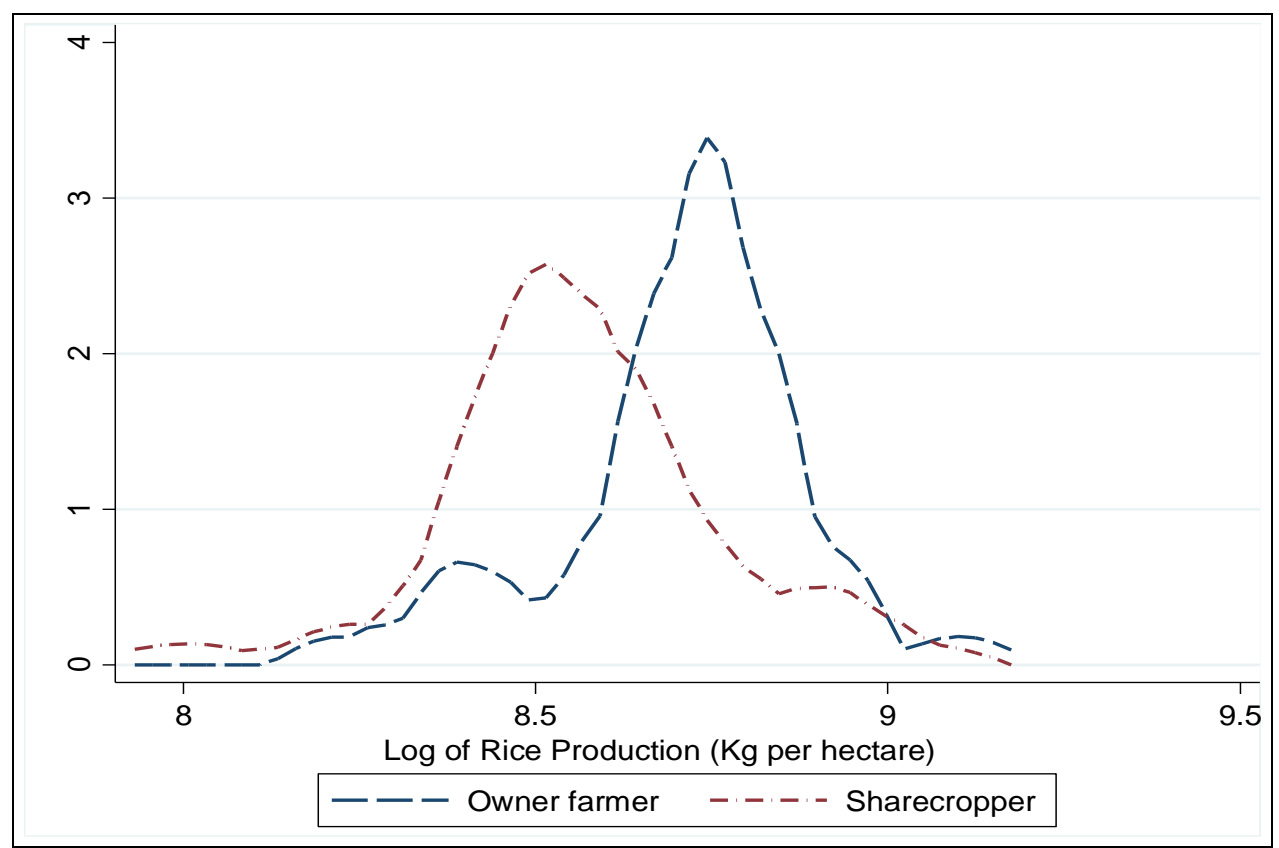

Fig. 2. Kernel Distribution of the Output by Land Tenancy Structure.

Source: Authors compilation based on field survey (2014)

According to the Marshallian inefficiency argument, it was assumed that sharecropping might influence the crop yields. In order to test the inefficiency hypothesis of sharecropping on rice production, a Cobb-Douglas form of production function (Equation 1) was used to estimate the relationship between ownership pattern of rice farm and volume of production. The farm specific characteristics and other explanatory variables of production function (Table 2) showed the use of factors of production and nature of farming of both the sharecropper and owner farmers.

In case of the mean difference in output as well as inputs between the owner farmers and sharecroppers, the former group of farmers outperformed the later one regarding the use of the quantity of seeds, fertilizers, labor, and use of modern variety including hybrid seeds and high yielding varieties (HYVs). In the context of the Northeast region of India, Goswami (2015) found that the sharecroppers did not intensively use the land and undersupplied labor in agriculture. In addition, the land size of the owner farmers was significantly higher than the sharecroppers (Table 2). The reason might be the lack of land ownership by the sharecroppers. Thus, they were dependent on the other's land for rice cultivation. As the sharecroppers were dependent on the land of other landowners they might get less access to land for cultivation, and thus, their farm size is small compared to the owner farmers. 
Table 2. Farm Specific Characteristics of the Sample Boro Rice Farmers

\begin{tabular}{|c|c|c|c|}
\hline \multirow[t]{2}{*}{ Particular } & $\begin{array}{c}\text { Owner Farmer } \\
\text { (a) }\end{array}$ & $\begin{array}{l}\text { Sharecropper } \\
\text { (b) }\end{array}$ & $\begin{array}{c}\text { Mean Difference } \\
{[(\mathrm{a})-(\mathrm{b})]}\end{array}$ \\
\hline & Mean & Mean & Mean \\
\hline Yield $\left(\mathrm{kg} \mathrm{ha}^{-1}\right)$ & 6113.653 & 5332.207 & $781.446 * * *$ \\
\hline Land size (ha) & 0.460 & 0.364 & $0.095 * *$ \\
\hline Seed $\left(\mathrm{kg} \mathrm{ha}^{-1}\right)$ & 41.998 & 41.410 & 0.588 \\
\hline Fertilizers $\left(\mathrm{kg} \mathrm{ha}^{-1}\right)$ & 448.660 & 440.572 & 8.088 \\
\hline Labor (No. ha-1) & 197.167 & 187.132 & 10.035 \\
\hline Pesticides $\left(\mathrm{kg} \mathrm{ha}^{-1}\right)$ & 8.252 & 8.273 & -0.021 \\
\hline Ploughing (BDT ha-1) & 6448.20 & 6275.00 & 173.2 \\
\hline Irrigation $\left(\mathrm{BDT} \mathrm{ha}^{-1}\right)$ & 47.255 & 42.608 & 4.647 \\
\hline $\begin{array}{c}\text { Type of seed (Modern variety }= \\
1 ; \text { otherwise }=0)\end{array}$ & 0.150 & 0.075 & 0.075 \\
\hline $\begin{array}{l}\text { Nature of farming (full time }=1 ; \\
\quad \text { Part time }=0 \text { ) }\end{array}$ & 0.525 & 0.400 & 0.125 \\
\hline $\begin{array}{l}\text { Crop rotation (same crop }=1 ; \\
\text { different crop }=0\end{array}$ & 0.775 & 0.750 & 0.025 \\
\hline $\begin{array}{l}\text { Cropping pattern (single crop }=1 \text {, } \\
\text { different }=0 \text { ) }\end{array}$ & 0.675 & 0.825 & -0.150 \\
\hline
\end{tabular}

N.B: $\quad * * *, * *$ and $*$ indicate the differences between owner farmer and sharecropper are significant at $1 \%(p<0.01), 5 \%(p<0.05)$ and $10 \%(p<0.10)$ level respectively.

The cost structure of rice cultivation was mentioned in BDT ha $a^{-1}$ where 1 US $\$=$ 78.00 Bangladeshi Taka (BDT) at the time of survey (June, 2014)

Source: Authors compilation based on field survey (2014)

Table 3. Estimation of Production Function

\begin{tabular}{l|c|c|c}
\hline \multicolumn{1}{c}{ Explanatory variables } & $(1)$ & $(2)$ & $(3)$ \\
\cline { 2 - 4 } & Model 1 & Model 2 & Model 3 \\
\hline Land $\left(\mathrm{X}_{1}\right)$ & 0.062 & 0.005 & 0.031 \\
& $(0.055)$ & $(0.055)$ & $(0.063)$ \\
Seed $\left(\mathrm{X}_{2}\right)$ & 0.121 & 0.125 & 0.164 \\
& $(0.121)$ & $(0.115)$ & $(0.122)$ \\
Fertilizers $\left(\mathrm{X}_{3}\right)$ & $0.468 * * *$ & $0.384 * * *$ & $0.414 * * *$ \\
& $(0.147)$ & $(0.142)$ & $(0.146)$ \\
Human labor $\left(\mathrm{X}_{4}\right)$ & $0.284 * * *$ & $0.248 * *$ & $0.236^{* *}$ \\
& $(0.103)$ & $(0.098)$ & $(0.106)$ \\
\hline
\end{tabular}


Table 3. Cont'd

\begin{tabular}{|c|c|c|c|}
\hline \multirow{2}{*}{ Explanatory variables } & $(1)$ & $(2)$ & (3) \\
\hline & Model 1 & Model 2 & Model 3 \\
\hline \multirow[t]{2}{*}{ Pesticides $\left(\mathrm{X}_{5}\right)$} & 0.046 & 0.054 & 0.046 \\
\hline & $(0.095)$ & $(0.090)$ & $(0.093)$ \\
\hline \multirow[t]{2}{*}{ Ploughing $\left(\mathrm{X}_{6}\right)$} & 0.007 & 0.020 & 0.022 \\
\hline & $(0.045)$ & $(0.042)$ & $(0.046)$ \\
\hline \multirow[t]{2}{*}{ Irrigation $\left(\mathrm{X}_{7}\right)$} & 0.039 & 0.034 & 0.030 \\
\hline & $(0.029)$ & $(0.027)$ & $(0.030)$ \\
\hline \multirow[t]{2}{*}{ Type of seed $\left(\mathrm{D}_{1}\right)$} & $0.141 * *$ & $0.121^{*}$ & $0.116^{*}$ \\
\hline & $(0.065)$ & $(0.062)$ & $(0.068)$ \\
\hline \multirow[t]{2}{*}{ Ownership pattern $\left(\mathrm{D}_{2}\right)$} & & $0.110 * * *$ & $0.112 * * *$ \\
\hline & & $(0.036)$ & $(0.038)$ \\
\hline \multirow[t]{2}{*}{ Experience of farming in year $\left(\mathrm{X}_{8}\right)$} & & & 0.001 \\
\hline & & & $(0.003)$ \\
\hline \multirow[t]{2}{*}{ Having training in farming $\left(\mathrm{D}_{3}\right)$} & & & 0.052 \\
\hline & & & $(0.041)$ \\
\hline \multirow[t]{2}{*}{ Nature of farming $\left(\mathrm{D}_{4}\right)$} & & & -0.046 \\
\hline & & & $(0.041)$ \\
\hline \multirow[t]{2}{*}{ Crop rotation $\left(\mathrm{D}_{5}\right)$} & & & 0.031 \\
\hline & & & $(0.046)$ \\
\hline \multirow[t]{2}{*}{ Cropping pattern $\left(\mathrm{D}_{6}\right)$} & & & -0.016 \\
\hline & & & $(0.051)$ \\
\hline \multirow[t]{2}{*}{ Household size $\left(X_{9}\right)$} & & & -0.005 \\
\hline & & & $(0.018)$ \\
\hline \multirow[t]{2}{*}{ Constant } & $3.621 * * *$ & $4.152 * * *$ & $3.945 * * *$ \\
\hline & $(0.828)$ & $(0.801)$ & $(0.852)$ \\
\hline Observations & 80 & 80 & 80 \\
\hline R-squared & 0.418 & 0.488 & 0.517 \\
\hline
\end{tabular}

N.B: Robust standard errors in the parentheses;

$* * *, * *$ and $*$ indicate the level of significance at $1 \%(p<0.01), 5 \%(p<0.05)$ and $10 \%(p<0.10)$, respectively

Source: Authors compilation based on field survey (2014)

The production function estimation revealed the effect of sharecropping on rice productivity in the study area. The result showed that the extent of variations in output when the farm was operated under the sharecropping system. In order to explore the impact of farm specific characteristics, ownership of the farm, and other farmer's and household level characteristics on rice production, three separate production functions were estimated (Table 3). The first regression result (model 1) showed that the use of fertilizers, human labor, and modern variety (MV) had a positive and significant effect on rice production (Table 3). 
The result implied that a one percent increase in fertilizers uses leads to an increase in output by an average of 0.40 percent. It could be inferred that as the marginal productivity of fertilizer was positive, there was an opportunity of using additional fertilizers to increase the volume of production. Land, seed, pesticides, ploughing irrigation, and crop rotation had also a positive impact on output, while they were not significant.

In model 2, the positive elasticity of land ownership indicated that owner farmers positively influenced the output as compared to the sharecroppers. The coefficient of the dummy variable $\mathrm{D}_{2}(\beta=0.11)$ indicated that holding other things constant, on an average owner farmers' output was $10 \%[=1-\exp (-$ $0.11)]$ higher than that of sharecroppers. It was observed that the sharecroppers had to share 35 percent to 50 percent of their output to the landowners as a rent of their land. Thus, higher rent demotivated the sharecroppers to supply the optimum level of input and also to use the land intensively. Some characteristics of the farmers were also added in model 3. None of them were found a significant influence on production volume.

Goswami (2015) noted the sharecroppers as the most inefficient group of farmers. Usually, the sharecroppers in this study were not monitored by the landowners. After getting the cultivation rights from the landowners, the sharecroppers took the decisions on production process and input use by themselves. In case of pure tenant, the landowners sometimes tried to intervene the output choice but they were not concerned about the input use and production process. However, in case of the cash tenant, the landowners are reluctant to intervene in production process, input use and even in output choice. Lack of monitoring by the landowners could be a reason of lower productivity by the sharecroppers. The study also found that around $60 \%$ of the pure sharecroppers did not share the cost of production while enjoyed a significant portion of output. In another case, it is mentioned earlier that the landowners enjoyed half of the output without sharing the cost of production. The existing cost sharing and output distribution between the sharecroppers and landowners might be a cause of lower productivity of sharecropping system. In the context of Pakistan, Jacoby and Mansuri (2009) found that there was no significant yield difference between the sharecroppers and owner farmers, while the owner farmers gained $18 \%$ more yield than the unmonitored sharecroppers. Therefore, monitoring could be an issue to make the farms more efficient and productive. The findings of this study indicated that compared to sharecropper the owner farmers were more efficient regarding the volume of rice production.

\section{Conclusions}

Among the several land tenure arrangements, the system of sharecropping is one of the usual systems of cultivation for the marginal as well as the landless 
farmers in the rural areas of Bangladesh. However, this system of cultivation is a concern in the present time regarding the productivity in rice cultivation because of the existence of the inefficiency hypothesis in sharecropping and rice production. The study findings revealed that the rice production of the owner farmer was significantly higher than the sharecropper. The owner farmers were more productive regarding the volume of output. The sharecroppers in the study areas used less amount of input such as seed, fertilizers, and human labor as well as spent less on ploughing and irrigation compared to the owner farmers. In addition, a lower percentage of sharecroppers used modern variety than the owner farmers.

The production difference between the sharecroppers and owner farmers revealed that the sharecroppers were less interested in providing their full effort in enhancing their farm productivity. The existing crop sharing ratio and cost sharing structure might be the reasons for less incentive of the sharecropper in applying the production enhancing inputs. Thus, the sharecroppers were more inefficient in rice productivity. In order to overcome the debate between sharecropping and agricultural productivity, the ratio of crop share should be favorable for the sharecropper, and that should be revised and uniform based on the cost sharing structure. In addition, the landowners should keep in touch with the use of their land by the tenant, which could motivate the sharecroppers to give full effort to apply the production enhancing inputs.

\section{References}

Acharya, R.N. and R.B. Ekelund. 1998. Mixed and pure sharecropping in Nepal: Empirical evidence supporting the traditional hypothesis. Applied Economics. 30 (1): 37-50.

Akanda, M.A.I., H. Isoda and S. Ito. 2008. Problem of sharecrop tenancy system in rice farming in Bangladesh: A case study on Alinapara village in Sherpur district. Journal of International Farm Management. 4 (2): 1-13.

Banerjee, A.V., P.J. Gertler and M. Ghatak. 2002. Empowerment and efficiency: Tenancy reform in West Bengal. J. Political Economy. 110 (2): 239-280

BBS. 2008. Agricultural Census 2008. Bangladesh Bureau of Statistics (BBS), Ministry of Planning, Government of the People's Republic of Bangladesh, Dhaka.

BBS. 2018. 45 Years Agriculture Statistics of Major Crops (Aus, Amon, Boro, Jute, Potato \& Wheat). Bangladesh Bureau of Statistics (BBS), Statistics and Informatics Division, Ministry of Planning, Government of the People's Republic of Bangladesh, Dhaka.

Braido, L.H. 2008. Evidence on the incentive properties of share contracts. Journal of Law and Economics. 51(2): 327-349.

Dubois, P. 2002. Moral hazard, land fertility and sharecropping in a rural area of the Philippines. Journal of Development Economics. 68 (1): 35-64. 
Goswami, B. 2015. Does tenure status affect the adoption of land productivity enhancing practices and input intensities? Evidence from Assam plains in India's northeast. Journal of Land and Rural Studies. 3 (1): 29-44.

Islam, M.A. and K.L. Maharjan. 2015. Farmers land tenure arrangements and technical efficiency of growing crops in some selected upazilas of Bangladesh. Bangladesh $J$. Agril. Research. 40(3): 347-361.

Jacoby, H.G. and Mansuri, G. 2009. Incentives, supervision, and sharecropper productivity. J. Dev. Econ. 88 (2): 232-241.

Johnson, D.G. 1950. Resource allocation under share contracts. The J. Polit. Econ. 58(2): 111-123.

Laffont, J.J. and M.S. Matoussi. 1995. Moral hazard, financial constraints and sharecropping in El Oulja. The Review of Economic Studies. 62 (3): 381-399.

Marshall, A. 1920. Principles of economics. Macmillan, London.

Nasrin, M. and M.T. Uddin. 2011. Land tenure system and agricultural productivity in a selected area of Bangladesh. Progressive Agriculture. 22(1-2): 181-192.

Pender, J. and M. Fafchamps. 2005. Land lease markets and agricultural efficiency in Ethiopia. J. African Econ. 15 (2): 253-84.

Ray, T. 2005. Sharecropping, land exploitation and land-improving investments. Japanese Economic Review. 56 (2): 127-143.

Sharma, N. and J. Drèze. 1996. Sharecropping in a north Indian village. The J. Dev. Studies. 33 (1): 1-39.

Tesafa, F. and M. Abera. 2014. Determinants and efficiency of sharecropping in rice production: The case of West Amhara Region, Ethiopia. J. Agril. Res. 2 (2): 18-30.

Zaman, M.R. 1973. Sharecropping and economic efficiency in Bangladesh. The Bangladesh Economic Review. 1 (2): 149-172. 